\title{
熱損失を伴う水素-空気予混合火炎の不安定性*
}

\author{
門 脇 敏*1, 中 屋 和 英*2
}

\section{Instability of Hydrogen-Air Premixed Flames with Heat Loss}

\author{
Satoshi KADOWAKI*3 ${ }^{* 3}$ and Kazuhide NAKAYA \\ *3 Department of Mechanical Engineering, Nagaoka University of Technology, \\ Kamitomioka, Nagaoka-shi, Niigata, 940-2188 Japan
}

\begin{abstract}
The instability of hydrogen-air premixed flames with heat loss has been investigated by twodimensional, unsteady calculations of reactive flows. The numerical model containing the detailed hydrogen-oxygen combustion with 17 elementary reactions of 8 reactive species and a nitrogen diluent, compressibility, viscosity, heat conduction, molecular diffusion, and heat loss of Newtonian type was used. Estimating the diffusive-thermal effect on the instability of premixed flames, the equivalence ratio was varied 0.75 to 1.25 . A sufficiently small disturbance was superimposed on a planar flame to obtain the dispersion relation and linearly most unstable wave number. To invistigate the characteristics of cellular flames, the disturbance with the linearly most unstable wave number, i.e. the critical wave number, was superimposed. The superimposed disturbance evolves owing to intrinsic instability, and then the cellular-flame front forms. With an increase in the heatloss parameter, the burning velocity of a cellular flame becomes monotonously smaller, which is due to the decrease in thermal expansion. However, the burning velocity of a cellular flame normalized by that of a planar flame at equivalence ratios lower than unity becomes larger near the quenching point.
\end{abstract}

Key Words: Premixed Combustion, Hydrogen Flame, Heat Loss, Intrinsic Instability

\section{1. はじめに}

近年, 燃料としての水素は, 低環境負荷の観点から 大きく脚光を浴びている. 現在, 多くの場合, 水素は 化石燃料から製造されているが, カーボンニュートラ ルであるバイオマス等からの製造も検討されている. 近い将来, バイオマス等からの水素の製造が軌道に乗 れば, 低環境負荷燃料の水素は, 次世代のエネルギー 資源として, 重要な役割を演じると思われる.

水素火炎の消炎距離は非常に短いので, 水素は超小 型燃焼器の燃料としても注目されている. 害用器にお ける燃焼過程では, 高温気体から周囲壁面への熱損失 が常に生じている. そして, この熱損失は, 燃焼速度 や消炎などの燃焼特性に多くの影響を及ぼすことが 知られている. 特に超小型燃焼器では, その影響が顕 著に現れるので, 熱損失に関する知見は燃焼器の実用 化を図る上で非常に重要である.

\footnotetext{
* 原稿受付 2006 年 3 月 20 日.

*1 正員, 長岡技術科学大学工学部 (䡤9 940-2188 長岡市上富岡 町).

*2 長岡技術科学大学大学院工学研究科.

E-mail : kadowaki@mech.nagaokaut.ac.jp
}

熱損失は燃焼速度や消炎などに影響を及ぼすが, 予 混合火炎の不安定性にも多大の影響を与える ${ }^{(1),(2)}$.こ れまでに, 非断熱火炎の不安定性が解析的に調べられ ており, 熱損失と安定/不安定領域との関係, 並びに 火炎不安定挙動との関倸が示されている(3)-(6). しかし, 気体の密度一定を仮定した拡散・熱的モデル方程式に 基づいているので, 熱膨張の効果（流体力学的効果） は考慮されていない, その後, 著者は, 流体力学的効 果を考虑した非断熱火炎の不安定性を, 圧縮性 Navier-Stokes 方程式に基づく数值計算を用いて調べ た ${ }^{(7)}$. そして，予混合火炎の不安定性に与える熱損失 効果を明らかにした. しかし，一段不可逆反応 (未燃 ガス $\Rightarrow$ 既然ガス）を仮定しているので, 各々の化学種 や化学反応が現象に及ぼす影響は明らかになってい ない.

これまでに, 著者は, 詳細な化学反応を考慮した水 素-空気予混合火炎（断熱火炎）の計算を遂行し，火 炎の固有不安定性を調べてきた ${ }^{(8)}$. それゆえ, 従来の 計算コードを改良して, 熱損失の効果を加えることに より, 非断熱火炎の不安定性を調べることが可能であ る. そこで本研究では, 改良した計算コードを用いて 
二次元非定常反応流れの数値計算を行い，水素-空気 予混合火炎の不安定性に及ぼす熱損失の影響を調べ る. そして, 火炎の不安定性を示す分散関係，並びに セル状火炎の形状や燃焼速度に及ぼす熱損失効果を 明確にする.

\section{2. 支眍方程式}

本研究では, 9 個の化学種 $\left(\mathrm{H}_{2}, \mathrm{O}_{2}, \mathrm{H}, \mathrm{O}, \mathrm{OH}, \mathrm{HO}_{2}\right.$, $\mathrm{H}_{2} \mathrm{O}_{2}, \mathrm{H}_{2} \mathrm{O}, \mathrm{N}_{2}$ ) と 17 個の素反応を考え, 反応速度 は Westbrook のデータ ${ }^{(9)}$ を採用する. 各化学種の輸送 倸数は, 分子動力学による理論計算により定める. そ して, 多成分系における輸送係数の值は, 従来から提

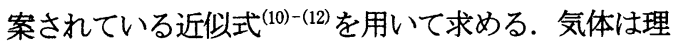
想気体の状態方程式に従うものとし, 外力, 体積粘性, 輻射, Soret 効果, Dufour 効果, 圧力勾配拡散は無視 する. また，熱損失は，ニュートンの冷却の法則に従 う,つまり気体と末燃ガスとの温度差に比例すると仮 定する. 支配方程式として, 二次元非定常の圧縮性 Navier-Stokes 方程式を採用する. デカルト座標を用い, 気体の主流方向を $x$ 方向とし, 火炎面の接線方向を $y$ 方向とする.

本数值計算で用いる二次元非定常反応流れの支配 方程式は，以下の通りである.

各化学種の連続の式

$$
\begin{array}{r}
\frac{\partial}{\partial t}\left(\rho Y_{i}\right)+\frac{\partial}{\partial x}\left(\rho Y_{i} u-\rho D_{i} \frac{\partial Y_{i}}{\partial x}\right) \\
+\frac{\partial}{\partial y}\left(\rho Y_{i} v-\rho D_{i} \frac{\partial Y_{i}}{\partial y}\right)=w_{i}
\end{array}
$$

\section{質量保存の式}

$$
\frac{\partial}{\partial t}(\rho)+\frac{\partial}{\partial x}(\rho u)+\frac{\partial}{\partial y}(\rho v)=0
$$

\section{運動量保存の式 $(x$ 方向 $)$}

$$
\begin{gathered}
\frac{\partial}{\partial t}(\rho u)+\frac{\partial}{\partial x}\left\{\rho u^{2}+p-\mu\left(\frac{4}{3} \frac{\partial u}{\partial x}-\frac{2}{3} \frac{\partial v}{\partial y}\right)\right\} \\
+\frac{\partial}{\partial y}\left\{\rho u v-\mu\left(\frac{\partial v}{\partial x}+\frac{\partial u}{\partial y}\right)\right\}=0
\end{gathered}
$$

運動量保存の式 $(y$ 方向 $)$

$$
\begin{aligned}
\frac{\partial}{\partial t}(\rho v) & +\frac{\partial}{\partial x}\left\{\rho u v-\mu\left(\frac{\partial v}{\partial x}+\frac{\partial u}{\partial y}\right)\right\} \\
+ & \frac{\partial}{\partial y}\left\{\rho v^{2}+p-\mu\left(\frac{4}{3} \frac{\partial v}{\partial y}-\frac{2}{3} \frac{\partial u}{\partial x}\right)\right\}=0
\end{aligned}
$$

エネルギー保存の式

$$
\begin{aligned}
& \frac{\partial}{\partial t}\left(\rho e_{\mathrm{t}}\right)+\frac{\partial}{\partial x}\left\{\left(\rho e_{\mathrm{t}}+p\right) u-\kappa \frac{\partial T}{\partial x}-\sum_{i}\left(h_{i} \rho D_{i} \frac{\partial Y_{i}}{\partial x}\right)\right\} \\
& +\frac{\partial}{\partial y}\left\{\left(\rho e_{\mathrm{t}}+p\right) v-\kappa \frac{\partial T}{\partial y}-\sum_{i}\left(h_{i} \rho D_{i} \frac{\partial Y_{i}}{\partial y}\right)\right\} \\
& =H\left(T-T_{\mathrm{u}}\right)
\end{aligned}
$$

状態式

$$
p=\left(\sum_{i} C_{i}\right) R T
$$

ここで, $\rho$ は密度, $Y$ は質量分率, $(u, v)$ は $(x, y)$ 方向 の速度成分, $p$ は圧力, $e_{\mathrm{t}}$ は全エネルギー, $T$ は温度, $C$ はモル濃度, $D$ は拡散係数, $w$ は反応速度, $\mu$ は粘

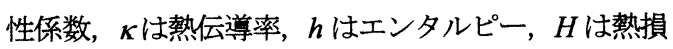
失パラメーター, $T_{\mathrm{u}}$ は未燃ガス温度, $R$ は一般気体定 数である. また, 添字 $i$ は, $i$ 番目の化学種を示して いる.

\section{3. 㝄算方法}

水素-空気予混合気の当量比は, $\phi=0.75 \sim 1.25$ とし, 上流の未燃ガスの温度と圧力は, $298 \mathrm{~K}$ と $1.013 \times 10^{5} \mathrm{~Pa}$ とする. 数值計算手法として, 時間・空間に対して共 に二次精度である陽的 MacCormack 法を採用する. 計 算領域は, $x$ 方向には $40 \mathrm{~mm}, y$ 方向には䍐乱の一波 長分とする. また, 時間ステップ間隔は $10 \mathrm{~ns}$ とする. 計算格子は, $x$ 方向には不等間隔格子を, $y$ 方向には 等間隔格子を用い，格子数は $1056 \times 33$ とする.ここ で, $x$ 方向の最小格子間隔は, $0.02 \mathrm{~mm}$ である. 計算 領域の上流側と下流側では, 流れ変数の勾配が連続で あるとする. 未燃ガスの流入速度 $S_{\mathrm{i}}$ は, 平面火炎の燃 焼速度 $S_{\mathrm{hl}}$ （当量比と熱損失パラメーターに依存）と 一致させる. また, $y$ 方向の境界では, 周期境界条件 を用いる.

\section{4. 平面火炎}

平面火炎の燃焼速度と熱損失パラメーターの関係 を示したのが図 1 である. 熱損失が大きくなると共に, 火炎の温度が低下するので, 平面火炎の燃焼速度は小 さくなる. また, 消炎点の近傍 $\left(H=H_{\mathrm{m}}\right)$ における燃 焼速度を断熱火炎の燃焼速度で除した值は, 各々の当 量比において大差なく, 約 0.6 である. そして,この 值は, 充分大きい活性化エネルギーを仮定した漸近解 析により得られた結果 ${ }^{(3)}$, (4) とほぼ一致している. 


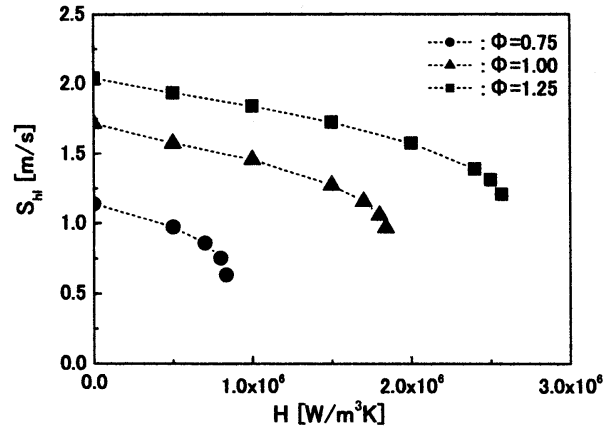

Fig. 1 Burning velocities of planar flames at $\phi=0.75$, 1.00 , and 1.25 , depending on the heat-loss parameter

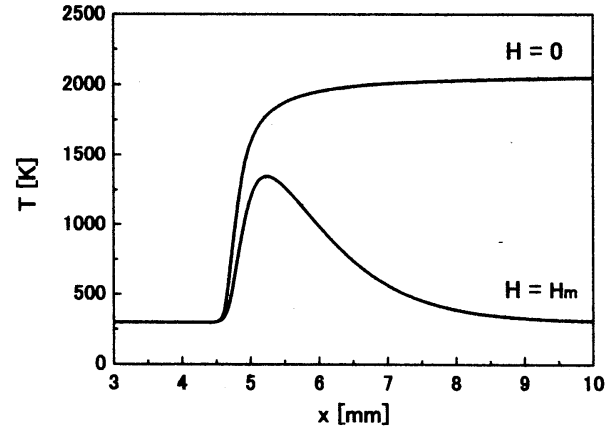

Fig. 2 Temperature distributions of planar flames under adiabatic and non-adiabatic conditions at $\phi=0.75$

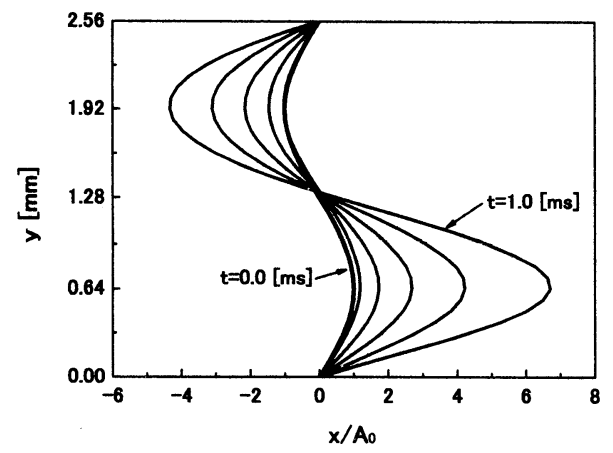

Fig. 3 Evolution of the disturbed flame front under adiabatic conditions at $\phi=0.75, \lambda=2.56 \mathrm{~mm}$, and $A_{0}=$ $0.02 \mathrm{~mm}(t=0.0,0.2,0.4, \ldots, 1.0 \mathrm{~ms})$

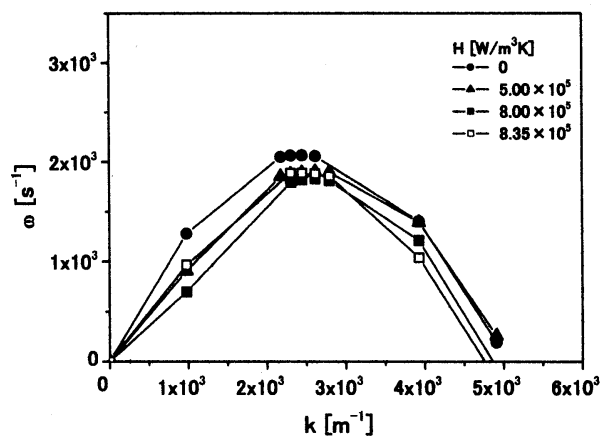

Fig. 4 Dispersion relations at $\phi=0.75$, depending on the heat-loss parameter

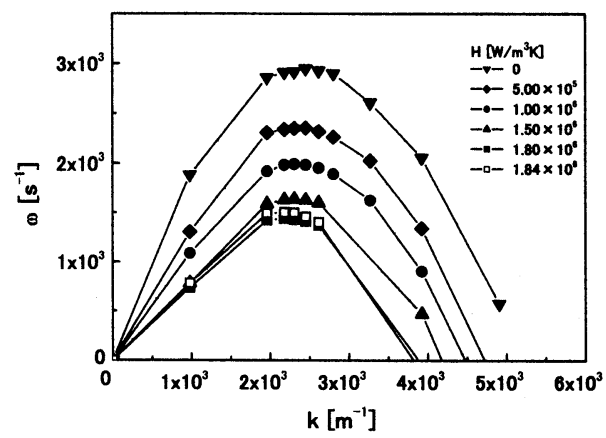

Fig. 5 Dispersion relations at $\phi=1.00$, depending on the heat-loss parameter

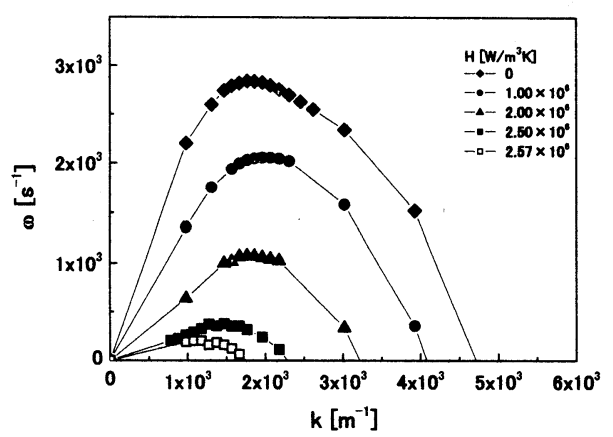

Fig. 6 Dispersion relations at $\phi=1.25$, depending on the heat-loss parameter 
図 2 は, $\phi=0.75$ における定在平面火炎の温度分布 を示したものである. 断熱火炎の場合 $(H=0)$ ，既 燃ガスの温度は断熱火炎温度に漸近する. 非断熱火炎 の場合 $\left(H=H_{\mathrm{m}}=8.35 \times 10^{5} \mathrm{~W} / \mathrm{m}^{3} \mathrm{~K}\right)$ ，既燃ガスの温 度は下流へ行くに従い減少する. また, 熱損失により, 火炎の温度は大きく低下する.

\section{5. 分 数関係}

予混合火炎の固有不安定性を調べるために, 正弦波 状の微小擾乱を平面火炎に加え, 挸乱の発達の様子を シミュレートする. 猡乱による火炎面の $x$ 方向への変 位は，以下の通りである。

$$
A_{0} \sin (2 \pi y / \lambda)
$$

ここで, $A_{0}$ は擾乱の初期振幅, $\lambda$ は擾乱の波長である.

擾乱の初期振幅は, $A_{0}=0.02 \mathrm{~mm}$ と設定する.

微小揌乱を断熱平面火炎に加えたときの時間毎の 火炎面形状を示したのが図 3 である $(\phi=0.75)$ 。こ こでは, $T=1500 \mathrm{~K}$ の所を火炎面の位置と定義してい る. 未燃ガスが左方から流入し, 既然ガスが右方へ流 出する. 横軸 $(x$ 軸) は, 摄乱の初期振幅で標準化さ れている. 火炎に加えられた啰乱の振幅は, 時間と共 に指数的に増大する.この様な猡乱の挙動は, 非断熱 火炎においても観察される. 増幅率 $\omega$ を以下の様に定 義する.

$$
\omega=\frac{d}{d t} \ln \left(A / A_{0}\right)
$$

ここで, $A$ は擾乱の振幅である. 上記の式から増幅率 を求めると， $\omega=2067 \mathrm{~s}^{-1}$ となる. なお，擾乱が時間に 対して指数的に大きくなるのは, その振幅が充分小さ いときのみである. 擾乱の振幅がある程度大きくなる と, その増幅率は小さくなり, 最終的にはほぼ零とな る.

撖乱の波長を変えて計算を行い, 各波長における増 幅率を求める. そして, 波数と波長の関倸

$$
k=2 \pi / \lambda
$$

を用いて, 増幅率と波数の関係, つまり分散関係を求 める.

図 4 は, $\phi=0.75$ における分散関係を示したもので ある. 熱損失が大きくなると共に, 増幅率は小さくな り, 不安定領域 (増幅率が正の領域) は狭くなる.こ れは, 熱損失により熱膨張の効果が小さくなるからで ある. また, 消炎点の近傍 $\left(H=H_{\mathrm{m}}=8.35 \times 10^{5} \mathrm{~W} / \mathrm{m}^{3} \mathrm{~K}\right)$ では，熱損失がそれより小さい場合 $(H=8.00 \times$ $\left.10^{5} \mathrm{~W} / \mathrm{m}^{3} \mathrm{~K}\right)$ と比較して, 増幅率は大きくなる．この 現象は, 一段不可逆反応を仮定した数值計算 ${ }^{(7)}$ では見 られなかった. その要因として, 燃料（水素）と酸化
剤 (酸素) の選択拡散と熱損失との相互作用が考えら れる. 断熱火炎の場合は, 気体の温度は下流へ行くに 従い単調に増加するが, 非断熱火炎の場合は, 火炎の 近くでピーク值を取る（図2 参照) 。選択拡散の効果 は, 気体の温度を局所的に変化させ, 火炎の不安定性 に影響を及ぼす。この効果は, 非断熱火炎の場合に顕 著になると思われる. なぜなら, 現象に多大な影響を 及ぼす温度のピーク值が, 選択拡散の効果により変化 するからである.この機構,つまり選択拡散と熱損失 との相互作用により, 消炎点の近傍における堌幅率が 大きくなると考えられる.

図 5 は, $\phi=1.00$ における分散関係を示したもので ある. 増幅率は，熱損失の増大と共に小さくなるが， 消炎点の近傍 $\left(H_{\mathrm{m}}=1.84 \times 10^{6} \mathrm{~W} / \mathrm{m}^{3} \mathrm{~K}\right)$ で僅かに大き くなる. 一方, $\phi=1.25$ のときは, 熱損失パラメータ 一が大きくなると共に増幅率は単調に減少し, 消炎点 の近傍 $\left(H_{\mathrm{m}}=2.57 \times 10^{6} \mathrm{~W} / \mathrm{m}^{3} \mathrm{~K}\right)$ で最小の值を取る (図 6).

\section{6. セル状火炎}

固有不安定性に起因して形成されるセル状火炎の 挙動を調べるために, 特性波長 (最大増幅率に対応す る波長) と等しい波長を持つ挸乱を平面火炎に加えて 計算を行う.ここでは, 猡乱の初期振幅を $A_{0}=0.2 \mathrm{~mm}$ と設定する.この值より小さい振幅をもつ啰乱を加え て計算を行っても, 得られる結果は同様である.

図 7 と図 8 は, 断熱及び非断熱条件下におけるセル 状火炎の挙動を示したものである $(\phi=0.75)$. 平面 火炎に加えられた擾乱は, 固有不安定性により発達し, セル状の火炎面が形成される. その後, セル状火炎は 上流側一移動する.これは, 火炎面積の増大により燃 焼速度が増加するからである. また, 燃焼速度の増分 は, セル状火炎の上流側への移動速度と等しくなる. なぜなら, 未燃ガスの流入速度と平面火炎の燃焼速度 を一致させているからである. 断熱及び非断熱条件下 における燃焼速度の増分が, $0.33 \mathrm{~m} / \mathrm{s}$ と $0.40 \mathrm{~m} / \mathrm{s}$ である ので, セル状火炎の燃焼速度 $S_{\mathrm{cf}}$ は, $1.47 \mathrm{~m} / \mathrm{s}$ と $1.03 \mathrm{~m} / \mathrm{s}$ となる.

図 9 と図 10 は, $\phi=1.25$ におけるセル状火炎の挙動 を示したものである. 固有不安定性によりセル状火炎 が形成され, 燃焼速度が増加し, 火炎は上流側へ移動 する. 断熱及び非断熱条件下における燃焼速度の増分 は, $0.58 \mathrm{~m} / \mathrm{s}$ と $0.03 \mathrm{~m} / \mathrm{s}$ である. この場合, $\phi=0.75$ の ときとは逆に, 断熱条件下における燃焼速度の増分は, 非断熱条件下におけるそれより大きくなる.また，セ ル状火炎の燃焼速度は, $2.62 \mathrm{~m} / \mathrm{s}$ と $1.24 \mathrm{~m} / \mathrm{s}$ である. 


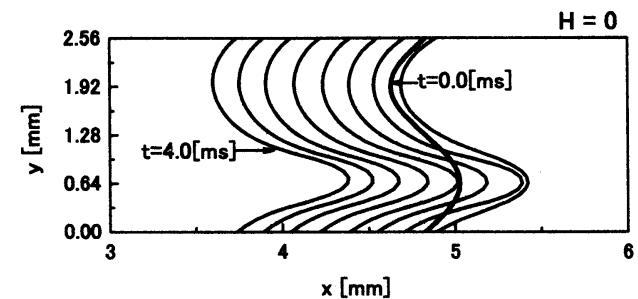

Fig. 7 Front shapes of the cellular flame under adiabatic conditions at $\phi=0.75, \lambda=2.56 \mathrm{~mm}, A_{0}=0.2 \mathrm{~mm}$, and $S_{\mathrm{i}}=$ $1.14 \mathrm{~m} / \mathrm{s}(t=0.0,0.5,1.0, \ldots, 4.0 \mathrm{~ms})$

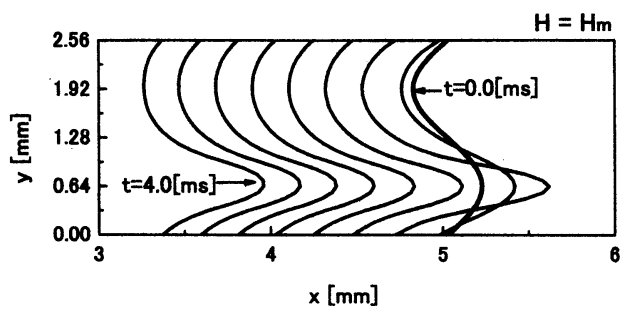

Fig. 8 Front shapes of the cellular flame under nonadiabatic conditions at $\phi=0.75, \lambda=2.56 \mathrm{~mm}, A_{0}=0.2 \mathrm{~mm}$, and $S_{\mathrm{i}}=0.63 \mathrm{~m} / \mathrm{s}(t=0.0,0.5,1.0, \ldots, 4.0 \mathrm{~ms})$

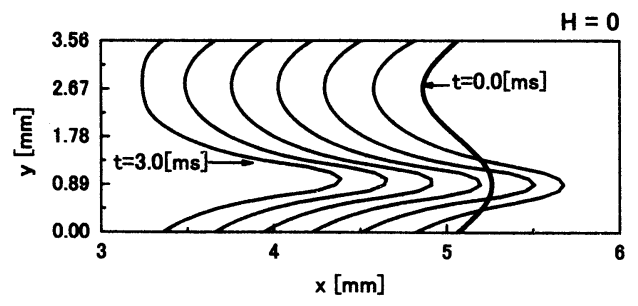

Fig. 9 Front shapes of the cellular flame under adiabatic conditions at $\phi=1.25, \lambda=3.56 \mathrm{~mm}, A_{0}=0.2 \mathrm{~mm}$, and $S_{\mathrm{i}}=$ $2.04 \mathrm{~m} / \mathrm{s}(t=0.0,0.5,1.0, \ldots, 3.0 \mathrm{~ms})$

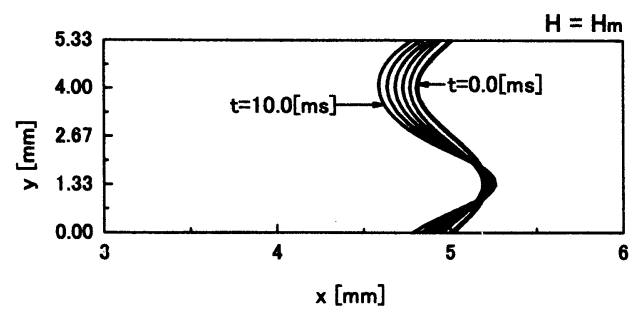

Fig. 10 Front shapes of the cellular flame under nonadiabatic conditions at $\phi=1.25, \lambda=5.33 \mathrm{~mm}, A_{0}=0.2 \mathrm{~mm}$, and $S_{\mathrm{i}}=1.21 \mathrm{~m} / \mathrm{s}(t=0.0,2.0,4.0, \ldots, 10.0 \mathrm{~ms})$

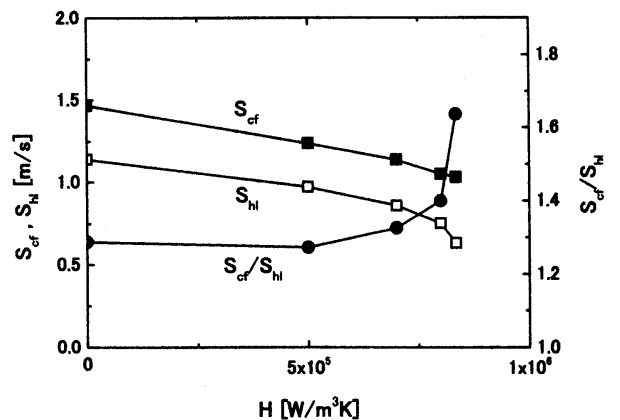

Fig. 11 Burning velocities of cellular flames, burning velocities of planar flames, and normalized burning velocities of cellular flames at $\phi=0.75$, depending on the heat-loss parameter

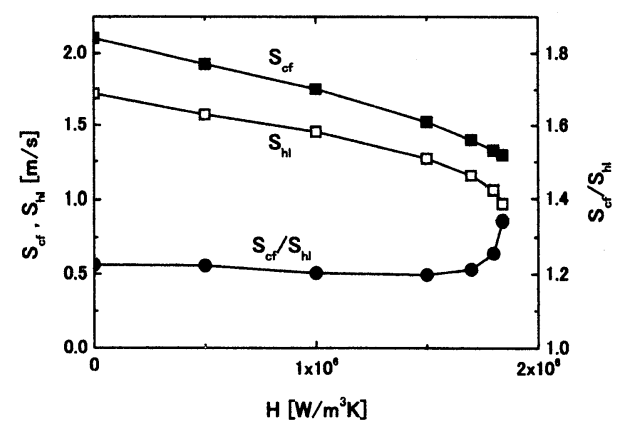

Fig. 12 Burning velocities at $\phi=1.00$, depending on the heat-loss parameter

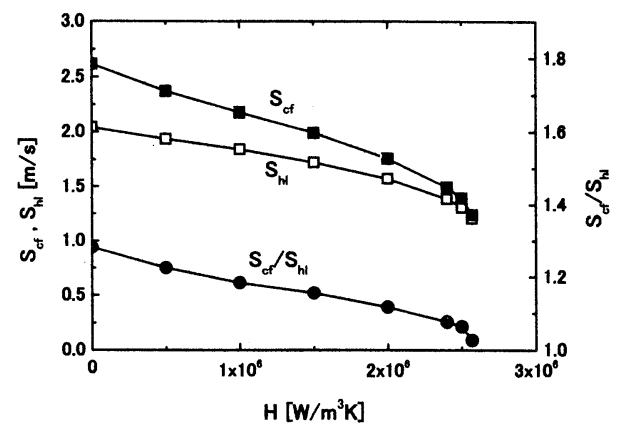

Fig. 13 Burning velocities at $\phi=1.25$, depending on the heat-loss parameter 

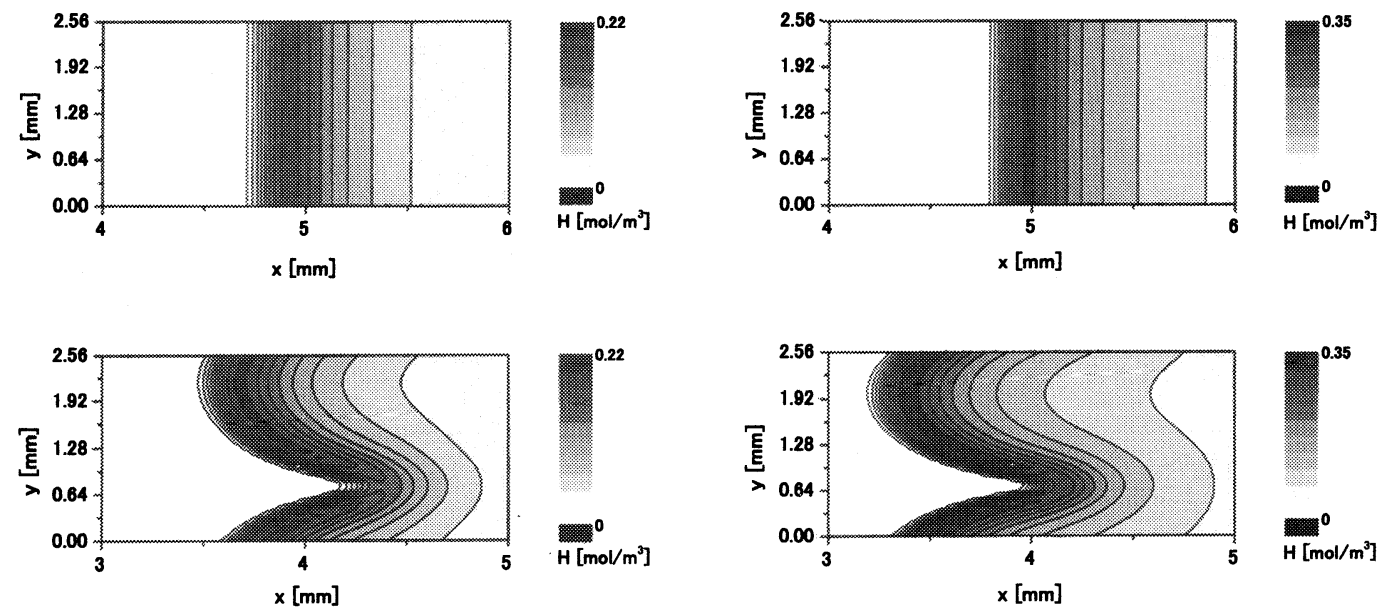

Fig. 14 Concentration distributions of hydrogen atom in planar and cellular flames under adiabatic conditions $(H=0)$ at $\phi=0.75$
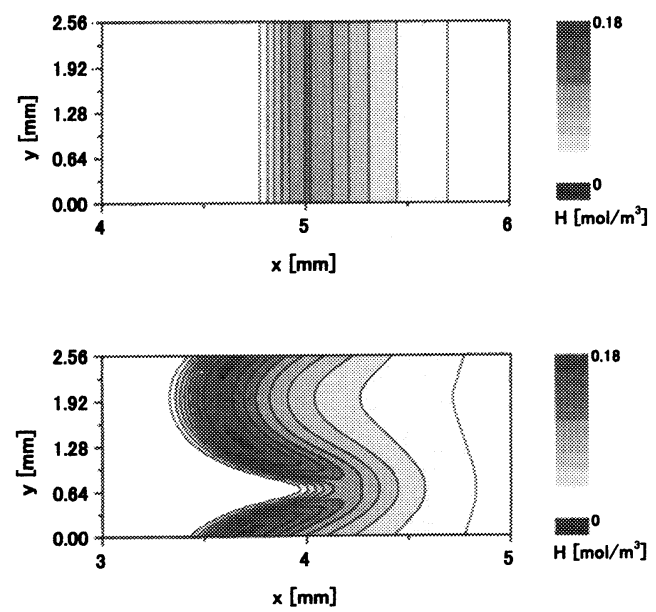

Fig. 15 Concentration distributions of hydrogen atom in planar and cellular flames under non-adiabatic conditions ( $H$ $\left.=H_{\mathrm{m}}\right)$ at $\phi=0.75$
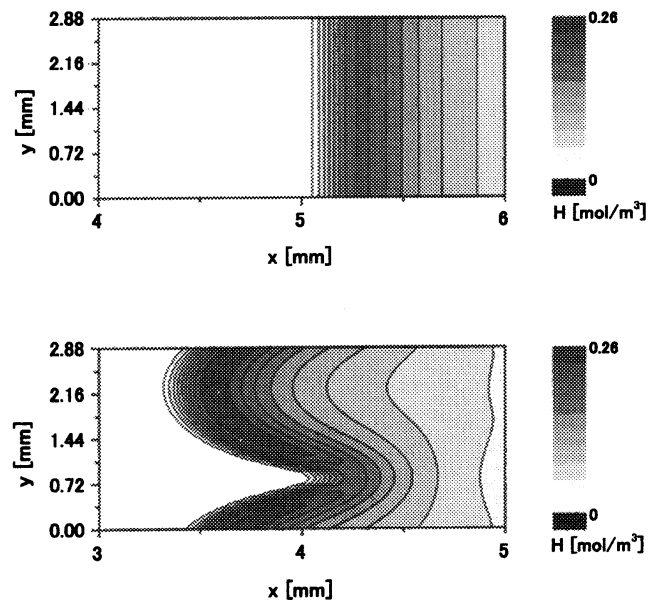

Fig. 17 Concentration distributions of hydrogen atom in planar and cellular flames under non-adiabatic conditions $(H$ $\left.=H_{\mathrm{m}}\right)$ at $\phi=1.00$ 
各々の熱損失におけるセル状火炎の燃焼速度, 平面 火炎の燃焼速度, 及び両者の比 (平面火炎の燃焼速度 で標準化したセル状火炎の燃焼速度) を示したのが図 11 である $(\phi=0.75)$. 熱損失パラメーターが大きく なると共に, $S_{\mathrm{cf}}$ と $S_{\mathrm{hl}}$ は単調に減少するが, $S_{\mathrm{cf}} / S_{\mathrm{hl}}$ は 単調に増加する. 特に, 消炎点の近傍では, 急激に增 大する. これは, 不足成分 (水素) の拡散係数が過剩 成分（酸素）のそれより大きいこと，並びに混合気の 熱拡散率より大きいことに拠るものと考えられる. 図 12 は， $\phi=1.00$ における各燃焼速度を示したものであ る. 標準化したセル状火炎の燃焼速度は, 熱損失が大 きくないとき,ほぼ一定の值を保持している. しかし， 消炎点の近傍では, その值が増加している. 流体力学 的効果のみにより形成されるセル状火炎では, $S_{\mathrm{cf}} / S_{\mathrm{hl}}$ の值は熱損失の大きさによらずほぼ一定である ${ }^{(7)}$. し たがって, $\phi=1.00$ において $S_{\mathrm{cf}} / S_{\mathrm{hl}}$ の值が消炎点の近 傍で増加しているのは, 選択拡散と熱損失との相互作 用がセル状火炎の燃焼速度に影響を及ぼすためと考 えられる. 図 13 は, $\phi=1.25$ における各燃焼速度を示 したものである. 全ての燃焼速度が熱損失の増大と共 に単調に減少する.

標準化したセル状火炎の燃焼速度が消炎点の近傍 で急激に増大することを調べるために, 平面火炎とセ ル状火炎における水素原子の濃度分布を求める. 断熱 条件下における水素原子の濃度分布を示したのが図 14 である（ $\phi=0.75 ）$. 未燃ガス側に凸な火炎面にお いて, 水素原子の濃度は高くなる. 加えて, この領域 では, 気体の温度も高くなり, 局所的燃焼速度も大き くなる.これは，選択拡散によるものと考えられる. 非断熱条件下における濃度分布を示したのが図 15 で ある. 水素原子濃度の変化量は, さらに大きくなる. これは, 選択拡散と熱損失の相互作用に拠るものと考 えられる. この相互作用により， $S_{\mathrm{cf}} / S_{\mathrm{hl}}$ の值は, 熱損 失と共に単調に増加する. 図 16 と図 17 は, $\phi=1.00$ における濃度分布を示したものである. 断熱条件下の 場合（図 16）, 平面火炎とセル状火炎における水素 原子濃度には，大きな差が見られない，しかし，非断 熱条件下の場合（図 17），未燃ガス側に凸な火炎面 において, 水素原子の濃度は高くなる.この機構によ り, 消炎点の近傍において $S_{\mathrm{cf}} / S_{\mathrm{hl}}$ の值が増大すると思 われる.この特性には, 選択拡散が強く作用している と考えられる.

\section{7.おわりに}

詳細な化学反応を考虑した水素-空気予混合火炎の 数值計算を行い, 固有不安定性に及ぼす熱損失の影響
を調べた. そして, 火炎の不安定性を示す分散関倸, 並びにセル状火炎の形状や燃焼速度を求め, 熱損失の 役割を明らかにした. 得られた結論は以下の通りであ る.

1) 熱損失が大きくなると共に, 増幅率は小さくな り, 不安定領域は狭くなる.これは, 固有不安定性に 対する熱膨張の効果が, 熱損失により小さくなるから

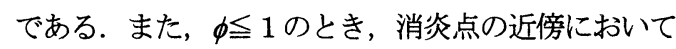
増幅率は僅かに大きくなる.

2) 平面火炎に加えられた擾乱は，固有不安定性に より発達し, セル状の火炎面が形成される. セル状火 炎の燃焼速度は, 熱損失パラメーターの増大と共に単 調に減少する. しかし，それを平面火炎の燃焼速度で 除した值は, 熱損失パラメーターへの依存性が当量比 により大きく異なる.つまり, $\phi=0.75(<1)$ のと き, $S_{\mathrm{cf}} / S_{\mathrm{hl}}$ は $H$ と共に単調に増加する. $\phi=1.00$ のと き, $S_{\mathrm{cf}} / S_{\mathrm{hl}}$ はほぼ一定の值を保持するが, 消炎点の近 傍で大きくなる. $\phi=1.25(>1)$ のとき, $S_{\mathrm{cf}} / S_{\mathrm{hl}}$ は単 調に減少する. この特性には, 選択拡散が強く作用し ていると考えられる.

\section{文献}

(1) Williams, F. A., Combustion Theory $2^{\text {nd }}$ Edition, (1985), pp. 349-365, Addison-Wesley.

(2) Sivashinsky, G. I., Ann. Rev. Fluid Mech., Vol. 15 (1983), pp. 179-199.

(3) Joulin, G. and Clavin, P., Combust. Flame, Vol. 35 (1979), pp. 139-153.

(4) Joulin, G. and Sivashinsky, G. I., Combust. Sci. Technol., Vol. 31 (1983), pp. 75-90.

(5) Buckmaster, J. and Jackson, T. L., Combust. Sci. Technol., Vol. 103 (1994), pp. 299-313.

(6) Kadowaki, S. and Fukugawa, T., Trans. Japan Soc. Mech. Engr., Ser. B, Vol. 70, No. 699 (2004), pp. 2883-2890.

(7) Kadowaki, S., Combust. Flame, Vol. 143 (2005), pp. 174-182.

(8) Kadowaki, S., Trans. Japan Soc. Mech. Engr., Ser. B, Vol. 61, No. 587 (1995), pp. 2718-2723.

(9) Westbrook, C. K., Combust. Sci. Technol., Vol. 29 (1982), pp. 67-81.

(10) Wilke, C. R., J. Chem. Phys., Vol. 18 (1950), pp. 517-519.

(11) Coffee, T. P. and Heimerl, J. M., Combust. Flame, Vol. 43 (1981), pp. 273-289.

(12) Wilke, C. R., Chem. Eng. Prog., Vol. 46 (1950), pp. 95-104. 